\title{
PEMANFAATAN INTERNET SEBAGAI MEDIA E-LEARNING UNTUK SISWA DAN GURU SMPN 3 TARAKAN
}

\section{Utilization Of Internet As E-Learning Media For Students And Teachers Of SMPN 3 Tarakan}

\author{
Nurmala $R$ \\ Jurusan Matematika, Fakultas Keguruan dan Ilmu Pendidikan, Universitas Borneo Tarakan \\ Email Korespondensi : nurmala.r17@gmail
}

\begin{abstract}
ABSTRAK
Tujuan kegiatan pengabdian kepada masyarakat ini untuk mengetahui proses sosialisasi pemanfaatan internet sebagai salah satu media e-learning untuk siswa dan guru SMPN 3 Tarakan. Metode pengabdian yang digunakan adalah metode deskriptif. Rancangan Pengabdian terdiri dari tahap persiapan, pelaksanaan, dan evaluasi. Sasaran kegiatan adalah siswa dan guru SMP Negeri 3 Tarakan dengan jumlah anak sekitar 20 orang yang terdiri dari masing-masing kelas 1, kelas 2, dan kelas 3 dan 5 orang guru. Hasil kegiatan pengabdian yaitu (1) kegiatan sosialisasi pemnafaatan internet sebagai media e-learning untuk siswa dan guru (2) Kegiatan sosialisasi dapat mendorong siswa supaya lebih giat belajar dan termotivasi untuk meningkatkan prestasi belajar dan (3) dengan kegiatan ini dapat menambah informasi, pengetahuan, dan wawasan tentang internet yang dapat diterapkan dalam proses pembelajaran.
\end{abstract}

Kata kunci : Internet, Media, E-Learning

\section{ABSTRACT}

The purpose of this community service is to find out the process of socializing the use of the internet as one of the e-learning media for students and teachers of SMPN 3 Tarakan. The service method used is descriptive method. The Service Design consists of the stages of preparation, implementation, and evaluation. The target of the activity is students and teachers of SMPN 3 Tarakan with a number of children around 20 people consisting of each class 1, class 2, and grade 3 and 5 teacher. The results of service activities are : (1) dissemination of internet communication activities as e-learning media for students and teachers, (2) Socialization activities can encourage students to be more active in learning and motivated to improve learning achievement, and (3) with this activity can add information, knowledge, and insights about the internet that can be applied in the learning process.

Keywords: Internet, Media, E-Learning

\section{PENDAHULUAN}

Teknologi Informasi dan Komunikasi sangat berkembang pesat terutama di Indonesia. Layanan internet yang ditawarkan pada pengguna smartphone maupun tablet memudahkan setiap orang termasuk siswa dalam mengakses informasi, baik informasi yang berdampak positif maupun negatif bagi siswa. APJII (Asosiasi Penyelenggara jasa Internet Indonesia) telah mengumumkan hasil survei data statistik pengguna internet Indonesia tahun 2016 adalah 132,7 juta user atau sekitar 51,5\% dari total jumlah penduduk Indonesia sebesar 256,2 juta. Dari keseluruhan pengguna internet, $18,4 \%$ atau 24,4 juta user berada pada usia 10-24 tahun, artinya usia sekolah berada pada bagian ini. Berdasarkan pekerjaan, $6,3 \%$ pengguna internet berstatus sebagai pelajar atau sekitar 8,3 juta user. Namun, besarnya pengguna internet ini lebih banyak mengakses media sosial dengan persentase tertinggi yaitu media sosial facebook sebesar 54\% atau sekitar 71,6 juta user. Meningkatnya penggunaan 
internet seperti pembahasan di atas, tentunya sangat berpengaruh dan dapat dimanfaatkan dalam bidang pendidikan. Media pembelajaran E-learning merupakan salah satu bentuk pemanfaatan teknologi informasi dan komunikasi dalam kegiatan pembelajaran. E-Learning merupakan singkatan dari Electronic Learning (pembelajaran elektronik), dapat diartikan sebagai pembelajaran yang menggunakan media elektronik. Alat yang digunakan dalam pembelajaran e-learning adalah komputer atau laptop dan jaringan internet. Pada kondisi di sekolah, teknologi informasi dan komunikasi digunakan sebagai alat bantu pembelajaran yang dapat membantu siswa dalam memperoleh infromasi yang up to date. Tujuan utama penggunaan media e-learning adalah untuk mewujudkan suasana belajar yang interaktif, menyenangkan, dan efektif termasuk dalam pembelajaran yang seringkali dianggap sulit dan membosankan oleh siswa.

Salah satu bentuk aplikasi dalam media e-learning adalah moodle. Moodle adalah sebuah program aplikasi berbasis internet yang dapat merubah sebuah media pembelajaran ke dalam bentuk web. Aplikasi ini memungkinkan siswa untuk masuk ke dalam "runag kelas" digital untuk memgakses materi-materi pembelajaran. Kata Moodle adalah singkatan dari Modulas Object-Oriented Dynamic Learning Environment. Moodle merupakan sebuah aplikasi Course Management System (CMS) yang gratis dapat didownload, digunakan ataupun dimodifikasi oleh siapa saja dengan lisensi GNU (General Public License). Aplikasi Modle dikembangkan pertama kali oleh Martin Dougiamas pada Agustuas 2002
VOLUME 2 NOMOR 2 DESEMBER 2018

dengan Moodle versi 1.0. Saat ini Moodle bisa dipakai oleh siapa saja secara Open Source.

Berdasarkan pengamatan yang telah dilakukan di SMP Negeri 3 Tarakan, bahwa pemahaman siswa dan guru tentang komputer dan akses internet tergolong baik dan didukung oleh fasilitas laboratorium yang lengkap. Namun realitas yang ada di sekolah tersebut pemanfaatan penggunaan laboratorium sebagai media pembelajaran kurang maksimal. Maka berdasarkan hal tersebut, Kegiatan pengabdian ini diharapakan dapat membantu siswa dalam memanfaatkan laboratorium yang ada sebagai salah satu media pembelajaran. Hal ini dapat dilakukan dalam bentuk pelatihan dan pendampingan pemanfaatan internet sebagai media pembelajaran berbasis e-learning, sehingga mampu mewujudkan kegiatan pembelajaran yang aktif, inovatif, kreatif, dan menyenangkan bagi siswa.

\section{METODE}

Metode pelaksanaan yang mengacu pada analisis situasi program yang disepakati dengan pihak sekolah selaku mitra yaitu SMPN 3 Tarakan untuk meningkatkan pengetahuan dan pengalaman siswa dalam memanfaatkan internet sebagai media e-learning dalam proses pembelajaram di sekolah.hal tersebut seperti yang diuraikan dalam tabel berikut:

Tabel 1. Metode Pelaksanaan Kegiatan Pengabdian

\begin{tabular}{|c|c|c|}
\hline ver & $\begin{array}{c}\text { Tishipiant } \\
\text { Pedaksinisien }\end{array}$ & Netnde \\
\hline 1 & 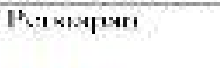 & 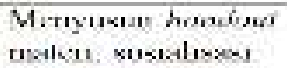 \\
\hline \multirow[t]{2}{*}{$z$} & 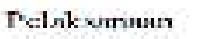 & 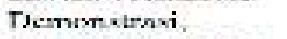 \\
\hline & Kequan & piaktik dain diskousi \\
\hline 5 & Evaluasi & Pembujicu snylu:l \\
\hline
\end{tabular}




\section{HASIL DAN PEMBAHASAN}

Kegiatan pengabdian kepada masyarakat dilaksanakan dengan acara tatap muka yang meliputi pemaparan dan penyampaian materi serta diskusi. Kegiatan ini berjalan dengan baik di sekolah mitra dan diikuti dengan antusias oleh siswa yang diutus untuk mengikuti kegoatan tersebut. Materi yang disampaikan pada kegiatan ini adalah tentang pemanfaatan internet sebagai media e-learning pembelajaran untuk siswa. Pada dasarnya internet merupakan salah satu sumber belajar yang sedang digandrungi oleh siswa-siswa saat ini. Karena hampir semua informasi yang berkaitan dengan pelajaran sekolah semua disajikan di dalam internet. Namun pada kenyataannya, belum semua siswa memahami pemanfaatan internet sebagai salah satu media e-learning dalam proses pembelajaran. Dengan adanya fasilitas yang telah disiapkan oleh sekolah, maka dengan sangat muda memberikan peluang untuk siswa memanfaatkan internet sebagai media pembelajaran dalam pelaksanaan proses pembelajaran.

Pemanfaatan internet bagi pendidikan adalah dapat menjadi akses sumber informasi, akses kepada narasumber, dan sebagai media kerja sama. Akses kepada sumber informasi yaitu sebagai perpustakaan on-line, akses hasil-hasil penelitian, dan akses kepada materi kuliah. Sedangkan akses kepada narasumber bisa dilakukan komunikasi tanpa harus bertemu secara fisik. Sedangkan sebagai media kerja sama internet bisa menjadi media untuk melakukan penelitian bersama atau membuat semacam makalah bersama. Penggunaan Internet dan web tidak hanya dapat memberikan konstribusi yang positif terhadap kegiatan akademik siswa, tetapi juga bagi guru. Internet dan web dapat memberi kemungkinan bagi guru untuk menggali informasi dan ilmu pengetahuan dalam mata pelajaran sesuai dengan bidang yang diampu. Melalui penggunaan Intenet dan web, guru akan selalu siap mengajarkan ilmu pengetahuan yang mutakhir kepada siswa. Hal ini tentu saja menuntut kemampuan guru itu sendiri untuk selalu giat mengakses web site dalam bidang yang menjadi kehaliannya. Tetapi disayangkan bahwa berdasarkan hasil observasi menunjukkan siswa dan guru melaksanakan proses belajar mengajar di ruang kelas saja tanpa mengaplikasikan teori kedalam bentuk praktik nyata. Guru hanya menyampaikan materi pelajaran dengan media buku dan papan tulis, tanpa menggunakan internet yang diperlukan dalam pemasaran online. Fungsi internet diantaranya yaitu: sebagai media melakukan transfer file, sebagai sarana mengirim surat (e-mail), sebagai pusat pembelajaran dan pendidikan, Sebagai sarana untuk penjualan atau pemasaran, Melakukan mailing list, newsgroup dan konferensi, chatting, mesin pencari (search engine), untuk mengirim sms ke telpon seluler dan sarana entertaimen dan permainan. Dengan demikian walaupun internet berpotensi untuk menyampaikan dampak yang positif dalam pembelajaran dan pendidikan, pengguna internet harus memiliki filter moralitas yang baik untuk menyeleksi informasi yang akan diperoleh agar dampak negatif dapat diminimalisir. 


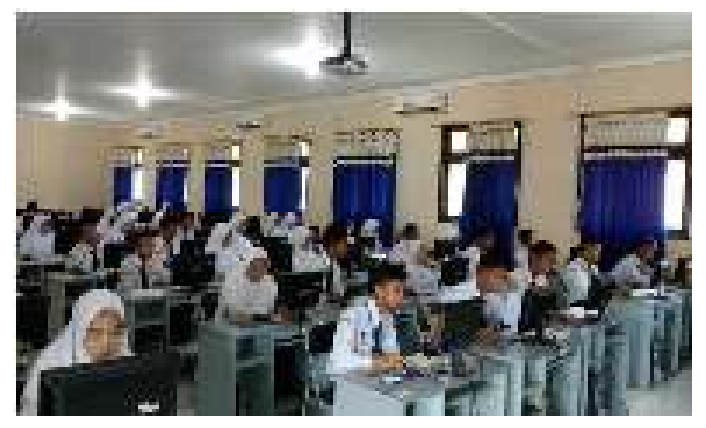

Internet dapat meningkatkan motivasi dan prestasi belajar siswa bila digunakan secara tepat dan baik. Namun, penggunaan internet yang kurang bijaksana bisa membuat siswa lupa waktu dan tidak belajar sehingga berakibat prestasi belajar menjadi menurun. Dengan diadakan kegiatan ini, diharapkan siswa dapat memanfaatkan internet untuk meningkatkan prestasi belajar dengan mengakses situs-situs yang dapat menambah pengetahuan dan wawasan. Dalam pelaksanaan kegiatan ini juga didapatkan bahwa ternyata selama ini guru hanya cendrung memngajar dikelas dengan fasilitas buku-buku yang ada tanpa memanfaatkan fasilitas lab komputer yang telah disediakan oleh sekolah. Dengan segala macam fasilitas yang disediakan, dapat digunakan oleh guru sebagai salah satu media pembelajaran di kelas dengan mengajarkan siswa untuk memanfaatkan internet dalam pembelajaran sesuai dengan kebutuhan mata pelajaran yang dipelajari oleh siswa.

\section{KESIMPULAN}

Berdasarkan kegiatan yang telah dilaksanakan diperoleh bahwa siswa dan

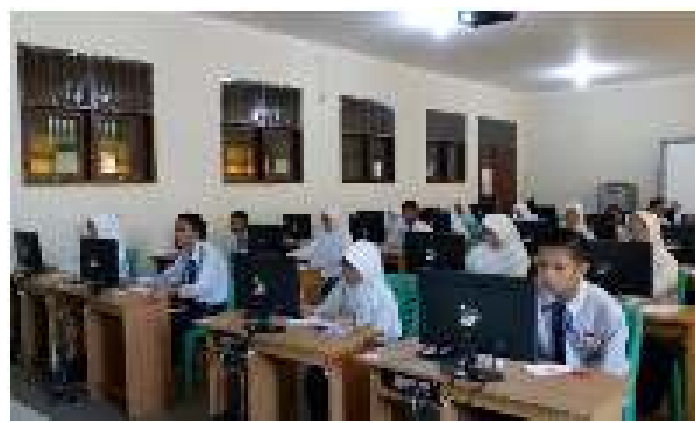

guru antusias dalam proses pembelajaran yang melibatkan penggunaan internet. Kegiatan yang seperti ini menjadi sangat penting untuk meningkatkan pengetahuan dan wawasan siswa tentang pemanfaatan internet. Selain itu, dapat meningkatkan profesionalisme guru dalam mengajar dengan menjadikan internet sebagai salah satu media pembelajaran.

\section{DAFTAR RUJUKAN}

Bloomsburg. 2006. E-Learning Concepts and Techniques. E Book. Institute for Interactive Technologies, Bloomsburg University of Pennsylvania, USA

Darmawan, Danim. (2012). Teknologi Pembelajaran. Bandung: PT. Remaja Rosdakarya.

Rifiana Arief \& Erlina , 2012, Modul Pelatihan Komputer dan Internet Bagi Guru Tentang Pencarian Referensi Bahan Ajar Melalui Internet dan Pengembangan Konten Website ELearning Sekolah, Gunadarma

Sapto Salimo, (2000), Panduan Praktis Elearning, Yogyakarta: Andi Offset.

Wati, Ega R. (2016). Ragam Media Pembelajaran. Jakarta: CV. Solusi Distribusi. 